\title{
Keberlangsungan ajaran sekte Bhairawa dalam kehidupan masyarakat Bali
}

Oleh

\author{
Ni Luh Gede Wariati, M. Fil.H \\ Dosen FBW IHDN Denpasar
}

\begin{abstract}
In the history of the development of Hinduism in the archipelago, it is mentioned that Bhairawa sect never developed in Indonesia. The Bhairawa sect is also said to have flourished in Bali so that Bhairawa s teachings must have been carried out in Bali. As we know that cultural and religious activities in Bali cannot be separated from the influence of sects that ever developed in Bali in the past. Although the Bhairawa sect is now abandoned in Bali, the influence of this sect may still be present in the religious life of Balinese society. That's why research is needed to know the existence of the Bhairawa sect in the religious life of Balinese society. Based on the results of the research, it was found that (1) the teachings of the Bhairawa sects were merged together with the Balinese customs tradition, this could be seen from the worship of the Goddess Durga in the Dalem temple, the ngelawar activity, the Calon Aarang activity, the use of arak and berem in religious activities, mecaru and Kebo Edan temple as a place of begging descent. (2) The influence of the Bhairawa sect for the Balinese Hindu Society can be seen in two specs, the first influence is on the Bhuana Agung (universe) and the influence on Bhuana Alit (human).
\end{abstract}

Keywords: Bhairawa Sect

\section{Pendahuluan}

Dalam sejarah perkembangan agama Hindu di Nusantara, disebutkan bahwa sekte Bhairawa pernah berkembang di Indonesia. Bhairawa adalah sekte rahasia dari sinkretisme antara agama Budha aliran Mahayana dengan agama Hindu aliran Siwa. Sekte ini muncul kurang lebih pada abad ke-6 M di Benggala sebselah timur. Dari sini kemudian tersebar ke utara melalui Tibet, Mongolia, masuk ke Cina dan Jepang. Sementara itu cabang yang lain tersebar ke arah timur memasuki daerah Asia Tenggara, termasuk Indonesia. (R. Pitono Hardjowardojo, 1966; 25)

Bhairawa Tantra merupakan bagian dari peradaban Jawa kuno. Banyak raja mengikuti sekte ini karena ritual-ritual dan simbol-simbol magisnya bisa digunakan untuk menganugerahi atau mengancam para bawahan. Ritual-ritual Bhairawa Tantra juga menetapkan ikatan mistis dan spiritual antara raja dan kawulanya sehingga memungkinkan raja untuk mendapatkan kekuasaan yang lebih besar. (Paul Michel Munoz, 2009;172)

Bila mendengar sekte Bhairawa maka yang pertama kali terbersit dalam pikiran pastilah sesuatu yang menyeramkan dan mengerikan. Ritual-ritual yang mengerikan dan penuh magis diidentikkan dengan sekte ini. Berdasarkan penjelasan sebelumnya maka diketahui bahwa sekte Bhairawa pernah berkembang di Bali, sehingga ajaran-ajaran Bhairawa pastinya pernah juga dilakukan di daerah Bali. Seperti yang kita ketahui bahwa, kebudayaan dan aktivitas agama di Bali tidak bisa terlepas dari pengaruh sekesekte yang pernah berkembang di Bali pada masa lalu. Sekte-sekte tersebut turut serta mewarnai dan memperkaya tradisi dan aktivitas religius masyarakat Bali. Sekte-sekte tersebut mungkin tidak lagi eksis dalam bentuk utuh, namun ajarannya pasti saja ada yang menyatu dalam tradisi dan aktivitas religius masyarakat. Ajaran 
sekte Bhairawa juga pernah memberi pengaruh dalam kehidupan religius masyarakat Bali, sehingga pastinya ajaran dari sekte bhairawa ada yang mesih digunakan bahkan berkembang dalam kehidupan religius masyarakat Bali.

\section{Rumusan Masalah}

Dalampenelitianiniakandikajipermasalahan pokok yaitu seperti apa keberlangsungan ajaran sekte Bhairawa dalam kehidupan religius masyarakat Bali. Dari permasalahan pokok tersebut maka dirumuskan dalam dua pertanyaan penelitian yaitu :

1. Bagaimana sekte Bhairawa dalam aktivitas masyarakat Bali?

2. Bagaimana pengaruh sekte Bhairawa dalam kehidupan masyarakat Bali?

\section{Ajaran sekte Bhairawa}

Sekte Bhairawa adalah salah satu sekte yang pernah berkembang di Bali. Bhairawa adalah sekte rahasia dari sinkretisme antara agama Budha aliran Mahayana dengan agama Hindu aliran Siwa. Sekte ini muncul kurang lebih pada abad ke-6 M di Benggala sebelah timur. Dari sini kemudian tersebar ke utara melalui Tibet, Mongolia, masuk ke Cina dan Jepang. Sementara itu cabang yang lain tersebar ke arah timur memasuki daerah Asia Tenggara, termasuk Indonesia (R. Pitono Hardjowardojo, 1966; 25).

Menurut maknanya "bhairawa" berarti menakutkan atau mengerikan. Bhairawa merupakan salah satu perwujudan Dewa Siwa dalam aspek peleburan dengan perwujudan yang sangat menyeramkan. Bhairawa juga dikenal dalam berbagai bahasa dengan berbagai sebutan, misalnya: Bhairava (Sanskrit), Bheruji (Rajasthan), Vairavar (Tamil) dan bila semua kata tersebut dihubungkan aspek Dewa Siwa, maka makna kata Bhairawa berarti "peleburan"( I Wayan Miasa, 2012:1).

Damar Shashangka (2010: 1) menyebutkan bahwa Ajaran Bhairawa dalam hubungannya dengan Tantrayana ada tiga aliran yaitu: Bhairawa
Hala Cakra merupakan pertemuan ajaran Buddha dengan ajaran Tantrayana. Bhairawa Heru Cakra merupakan ajaran yang muncul dari tradisi kepercayaan Indonesia bercampur dengan Hala Cakra. Bhairawa Bima Sakti adalah pertemuan antara ajaran Bhairawa dengan ajaran Siwa.

Kriya Yoga Nusantara (2016:1) menjelaskan bahwa pengikut sekte Bhairawa Tantra berusaha mencapai kebebasan dan pencerahan (moksa) dengan cara yang sesingkat-singkatnya. Ciri-ciri mereka adalah anti asketisme dan anti berpikir. Menurut mereka, pencerahan bisa diraih melalui sebuah kejenuhan total terhadap kenikmatan duniawi. Oleh karena itu, pengikut sekte ini justru melakukan ritual-ritual tertentu yang bagi selain mereka dianggap sebagai larangan. Ritual mereka bersifat rahasia dan sangat mengerikan, yaitu menjalankan Pancamakarapuja atau malima (lima Ma) dengan sebaik-baiknya dan sebanyakbanyaknya. Lima Ma tersebut adalah :

1. Matsya : makan ikan sepuas-puasnya,

2. Mamsa : makan daging sepuas-puasnya,

3. Madya : minum minuman hingga mabuk,

4. Madra : tarian hingga mencapai ekstase, dan

5. Maithuna : upacara seksual

Ritual Pancamakara yang bersumber dari kitab Kali Mantra dan kitab Mahanirvana Tantra jelas disebutkan sebagai berikut :

Sadayam bhaamsaca miinam ca mudraa naithuna se vaca, Ete Pamca Makaaraa syu Mokshadaah Kaluyuge

Artinya:

"Mabuk, memakan daging, memakan ikan,melakukan sexualitas dan meditasi, akan menuntun kepada Moksha pada jaman Kaliyuga ini."

Maha Nirvana Tantra :

"Pautvaa pitvaa punah pitvaa yaavat patati bhuutale, Punarutyaaya dyai potvaa punarjanma ga vidhate." 
Terjemahannya :

"Minum, teruslah minum hingga kamu terjerembab ke tanah. Lantas berdirilah kembali dan minum lagi hingga sesudah itu kamu akan terbebas dari punarjanma (kelahiran kembali) dan mencapai kesempurnaan. (Moksha)."

Maksud dari ayat yang dipaparkan dalam Kitab Kali Mantra adalah, dengan ritual sebagaimana tersebut dibawah ini, maka akan dicapai Moksha pada jaman Kaliyuga yang tengah berlaku sekarang.

Sekte Bhairawa dalam aktivitas religius masyarakat Bali

\section{a. Pemujaan terhadap Dewi Durgha di pura Dalem}

Seperti yang kita ketahui bahwa salah satu ciri dari Sekte Bhairawa adalah adanya pemujaan terhadap Sakti Siwa, yaitu Dewi Durga sebagai Dewi tertinggi. Di Bali tidak ada hari khusus untuk memuja Dewi Dhurga karena di Bali pada umumnya Dewi Durgha berstana di Pura Dalem dan odalan masing-masing pura dalem di Bali berbeda-beda. Namun setiap daerah di Bali memiliki pura dalem dan ada pemujaan Dhurga disana. Pemujaan di Pura dalem rutin dilakukan oleh masyarakat Bali setiap 6 bulan sekali.

\section{b. Ngelawar}

Lawar adalah salam satu makanan khas masyarakat Bali. Setiap acara-acara agama atau masyarakat biasanya tidak bisa lepas dari ngelawar. Walaupun ada beberapa asumsi negatif tentang lawar di masyarakat karena menggunakan daging mentah dan darah segar, namun aktivitas ngelawar tidak bila dilepaskan dalam kegiatan religius masyarakat Bali. Ada beberapa daerah di Bali dimana penggunaan daging mentah saat ngelawar di minimalisir atau darah disiram dengan air hangat terlebih dahulu, namun walaupun begitu aktivitas ngelawar tetap eksis. Pemahaman tentang kesehatan tidak membuat masyarakat meninggalkan kegiatan ini, namun cara pembuatannya yang mulai dirubah.

\section{c. Pementasan Calon Arang}

Calon Arang masih sering dipentaskan di daerah Bali, biasanya pementasan Calon Arang dilakukan pada saat odalan di Pura Dalem. Di Pura Kebo Edan sendiri pementasan Calon Arang masih dilakukan. Ngakan Putu Duaja selaku Mangku dari Pura Kebo Edan mengatakan bahwa “ di Pura Kebo Edan juga dilakukan pementasan Calon Arang, namun tidak rutin paling tidak satu tahun sekali, di pura Kebo Edan juga melinggih Ratu Ayu dan Barong Ket (Ratu Mas Gede) Beliaulah yang mesolah pada saat Calon Arang”. Keterangan ini menunjukkan bahwa Calon Arang masih eksis di Bali, walaupun tidak sering dilakukan, namun pada momen-momen tertentu pementasan Calon Arang harus dilakukan.

\section{d. Penggunaan arak dan berem dalam kegiatan upacara keagamaan}

Pelaksanaan ritual Hindu di Bali tidak bisa lepas dari arak dan berem. Dalam menghaturkan segehan, caru atau mesaagan, arak, berem, tuang dan air memiliki peranan penting. Minuman keras itu biasanya dituang terakhir. Pada kegiatan religius masyarakat Bali minuman keras juga digunakan sebagai sarana persembahan, arak, berem dan tuak digunakan sebagai persembahan kepada para Bhuta kala.

\section{e. Mecaru}

Mecaru dikatakan sebagai salah satu jejak sekte Bhairawa karena dalam caru menggunakan kurban berupa binatang atau ada menggunakan daging mentah dan darah. Mecaru atau bhuta yadnya adalah korban suci yang ditujukan kepada para bhuta kala dan sarwa prani, dimana dijelaskan pula bahwa bhuta kala tersebut adalah ciptaan dewi durga. Aktivitas mecaru sering dilakukan oleh umat Bali, bahkan ada yang disebut dengan Caru Gumi dimana dilakukan oleh seluruh masyarakat hindu Bali secara serentak. Caru ini biasanya dilakukan pada saat pengerupukan. 


\section{f. Pura Kebo Edan sebagai tempat memohon keturunan}

Walaupun terdapat beberapa arca yang menyeramkan, namun banyak masyarakat hindu yang bersembahyang ke pura kebo edan. Ada beberapa dari mereka yang memohon keturunan. Banyak masyarakat yang bersembahyang ke Pura Kebo Edan selain untuk memohon keselamatan, keturunan di pura ini juga bisa untuk memohon kesembuhan bukan hanya untuk manusia namun juga untuk ternak. Odalan di Pura Kebo Edan ini adalah pada saat Tumpek Kandang.

Permasalahan ajaran sekte Bhairawa yang lebur bersama adat tradisi masyarakat Bali

Seperti yang kita ketahui bahwa ajaran sekte Bhairawa mengerikan dan menyeramkan. Dalam pelaksanaan Caru ada binatang yang dikorbankan, bukan hanya dalam caru, namun dalam Panca Yadnya di Bali pastinya ada binatang yang akan dijadikan kurban. Pembunuhan hewan untuk dijadikan upacara Yadnya memang terlihat agak mengerikan, apalagi dalam beberapa ritual ada hewan yang dibunuh langsung dengan tangan bukan pisau. Namun apakah itu salah? Apakah membunuh hewan yang diperuntukkan yadnya merupakan tindakan keji?. Rudia Adiputra dalam wawancara mengatakan bahwa "dalam ajaran agama Hindu ada beberapa mantra yang diucapkan sebelum membunuh hewan untuk yadnya. Sebenarnya sebelum kita membunuh hewan tersebut, ketika kita doakan disana kita persembahkan dulu atma hewan tersebut kepada Beliau. Jadi sebenarnya kita tidak membuhuh, karena hewan yang kita sembelih Atmanya sudah kita persembahkan kepada Tuhan. Karena itulah sebelum menyembelih hewan ada mantra yang diucapkan".

Dalam ajaran agama Hindu terdapat mantra dalam menyembelih hewan yang terdapat dalam Lontar Dharma Caruban yang dimuat dalam buku Darma-Caruban (Tuntunan ngebat) oleh Parisada Hindu Dharma Kabupaten Tabanan (1984 : 4-6) yaitu :

\section{Dwi Pada: hewan yang berkaki dua;}

"Om Swasti swasti sarwa dewa bhuta sukha pradhana purusa sang yoga ya namah, Om Yang Nama Swaha"

Maksudnya:

Bagi binatang sembelihan yang berkaki dua dan yang sejenisnya rohnya dikembalikan ke arah timur kehadapan Bhatara Iswara, dengan harapan kelak apabila numitis rohnya itu kedunia akan menjadi manusia yang sakti dan indah perawakanya, tak tercela dan selalu bisa bersedana (beramal) yang baik serta sepanjang hidupnya selalu berpegangan pada Dharma.

\section{Catur Pada : hewan berkaki empat;}

"Om Swasti-swasti sarwa dewa bhuta sukha pradhana purusa sang yoga ya namah, Om Bang Namah Swaha"

Maksudnya :

Bagi binatang sembelihan yang berkaki empat seperti kerbau, sapi, babi dan sejenisnya rohnya dikembalikan ke arah selatan kehadapan Betara Brahma.

\section{Asta Pada : hewan berkaki delapan;}

"Om Swasti-swasti sarwa dewa bhuta sukha pradhana purusa sang yoga ya namah, Om Ung Namah Swaha"

maksudnya:

Bagi binatang sembelihan yang berkaki delapan seperti ketam, Udang dan sejenisnya rohnya dikembalikan ke arah Utara kehadapan Betara Wisnu.

4. Halaku - laku Dada : berjalan dengan Dada/ hewan melata;

"Om Swasti-swasti sarwa dewa bhuta sukha pradhana purusa sang yoga ya namah, Om Tang Namah Swaha”

Maksudnya :

Bagi binatang sembelihan yang berjalan dengan dada maka rohnya dikembalikan ke arah barat kehadapan Betara Mahadewa. 


\section{Sahang Samidha : kayu-kayu bakar;}

"Om Swasti-swasti sarwa dewa bhuta sukha pradhana purusa sang yoga ya namah, Om Nang Namah Swahya"

Maksudnya :

Bila menggunakan kayu bakar /menebang pohon roh kayu tersebut dikembalikan ke arah tenggara kehadapan betara Maheswara.

\section{Daun-daunan;}

"Om Swasti-swasti sarwa dewa bhuta sukha pradhana purusa sang yoga ya namah, Om Mang Namah Swaha”

Maksudnya:

bila menggunakan daun-daunan lebih lebih untuk kepentingan yadnya rohnya dikembalikan ke arah barat daya kehadapan Bethara Ludra.

\section{Suku Tunggal : berkaki satu;}

"Om Swasti-swasti sarwa dewa bhuta sukha pradhana purusa sang yoga ya namah, Om Sing namah Swaha”

Maksudnya:

Bagi penyembelihan binatang yang berkaki satu rohnya dikembalikan ke arah barat laut kehadapan bhatara Sangkara.

\section{Durpada: Hewan yang berkaki banyak;}

"Om Swasti-swasti sarwa dewa bhuta sukha pradhana purusa sang yoga ya namah, Om Wang Namah Swaha”

Maksudnya :

Apabila menyembelih binatang yang deyet (yang kakinya tak terhitung) maka rohnya dikembalikan ke arah timur laut ke hadapan Bhatara Shambu.

\section{Salwiring We: Jenis Ikan;}

"Om Swasti-swasti sarwa dewa bhuta sukha pradhana purusa sang yoga ya namah, Om yang namah swaha"

maksudnya :

Bila menyembelih segala jenis ikan rohnya dikembalikan ke arah tengah kehadapan Bhatara Siwa

Mantra memecikkan Tirta sebelum menyembelih baik untuk pisau, talenan:

Om Ung Siwa nirmala namah swaha,

Om sadasiwa nirmala dhirgaya nama swaha,

Om Paramasiwa Niroga namah swaha,

Om ksama sampurna namah swaha.

Berdasarkan ulasan di atas maka mengorbankan hewan untuk yadnya bukanlah tindakan keji. Berdasarkan sumber dalam pustaka suci Wrtisasana pada halaman 2, kirtya II/b/78/1, menurut Oka (1993:93) dijelaskan bahwa himsa (pembunuhan) terhadap binatang boleh dilakukan asal tujuannya membunuh untuk dewapuja (mengadakan pemujaan dewa-dewa), atithipuja (persembahan kepada tamu) dan walikramapuja yaitu (waktu upacara-upacara korban atau caru). Di samping itu diterangkan juga dalam buku itu binatang-binatang apa saja yang boleh dibunuh untuk tujuan suci itu, misalnya segala macam kidang, menjangan, burung, ikan, dan lain-lainnya yang boleh dibunuh sendiri di samping itik, unggas, ayam, babi, kerbau yang membunuhnya harus disuruh orang lain (Subagiasta I Ketut, 2007 :1). Membunuh untuk Yadnya bukanlah perbuatan keji dan kejam, pemahaman diatas membuat upacara yadnya tetap ajeg dan dilaksanakan di Bali.

Pengaruh Sekte Bhairawa dalam aktivitas religius masyarakat Bali

Setiap ajaran yang berkembang di Bali pastinya memiliki pengaruh terhadap lingkungan dan individu yang melaksanakan, begitu pula ajaran sekte bhairawa memiliki pengaruh yaitu:

\section{a. Pengaruh ajaran sekte Bhairawa terhadap Bhuana agung}

Donder (2007:77) menyebutkan bahwa Bhuwana Agung itu merupakan gabungan antara Bahasa Sansekerta dengan bahasa Kawi, yaitu bhuana berasal dari bahasa Sansekerta yang artinya; bumi, material atau benda; dan kata agung 
berasal dari bahasa Jawa Kuno, yaitu dari kata (geng, gong, ageng) yang artinya besar. Dengan demikian kata bhuana agung berarti bumi yang besar, yang dimaksud adalah alam semesta beserta seluruh ciptaannya yang ada. Dalam ajaran Agama Hindu, Bhuana Agung atau alam semesta terdiri atas beberapa unsure. Unsur-unsur tersebut dalam istilah Agama Hindu disebut Panca Maha Bhuta, yaitu lima unsur zat alamyang terdiri atas:

1. Pertiwi, yaitu zat padat

2. Apah, yaitu zat cair

3. Teja, yaitu zat sinar atau cahaya

4. Bayu, yaitu udara atau gas yang ada di sekitar manusia

\section{Akasa, yaitu Ether atau ruang.}

Upacara yadnya dalam hal ini caru tentunya berpengaruh terhadap bhuana agung, seperti yang kita ketahui bahwa tujuan dari caru atau mecaru adalah memohon kehadapan Ida Sang Hyang Widhi Wasa agar senantiasa kehidupan kita sebagai umat manusia ciptaan-Nya mendapatkan kehidupan yang baik dan secara sekala dan niskala. Rudia Adi Putra dalam wawancara mengatakan bahwa "tentu saja ada pengaruh dari ritual, yadnya atau caru terhadap bhuana agung, secara sederhana kita pikir caru diibaratkan upah untuk para bhuta, jadi jika para bhuta sudah mendapat makanan maka mereka tidak akan menganggu manusia. Bhuta itu sendiri khan ciptaan Ida Sang hyang Widhi juga, jadi sudah tentu untuk mendapatkan kehidupan yang harmonis maka hendaknya saling menjaga hubungan baik, termasuk kepada makhluk ciptaanNya yang tidak terlihat"

Sebenarnya apa yang disampaikan oleh Rudia Adi Putra sama dengan yang terdapat dalam Lontar Kala Tatwa dalam Pasek Swastika (2009:11) menyebutkan bahwa, seandainya bhutakala telah diberikan persembahan berupa caru, beliau senantiasa berubah wujud menjadi Dewa yang selanjutnya diharapkan akan menjada kehidupan umat manusia dan alam jagad raya ini dan tiada lagi menggoda kita yang akan selalu menjaga dan menolong segala bentuk kegiatan dan umat manusia khususnya di alam/tempat pelaksanaan caru.

Donder dalam wawancara juga mengemukakan hal yang sama "bahwa caru adalah alat yang digunakan manusia untuk mengembalikan atau menetralisir alam. Karena apa yang terjadi di alam sekarang ini adalah ulah dari manusia. Pikiran-pikiran yang beraneka ragam dan yang negatif membuat alam menjadi kacau, karena itu caru adalah salah satu alat yang digunakan untuk menetralisir alam. Namun beliau menekankan bahwa "Ritual is olny a tool, is not a goal". Masyarakat hendaknya memahami bahwa ritual apapun bentuknya adalah alat, dan bukan tujuan”. Berdasarkan ulasan di atas maka dapat diketahui bahwa ritual caru memberi pengaruh terhadap keharmonisan bhuana agung.

\section{b. Pengaruh bagi Bhuana Alit}

Bhuwana Alit adalah dunia kecil yang unsurunsurnya sama dengan Bhuwana Agung. Bhuwana Alit disebut juga dengan Mikrokosmos. Unsurunsur Bhuwana Alit pada diri manusia terdiri atas unsur Purusa menjadi Jiwatman, sedangkan unsur Prakerti menjadi bahan manusia, baik itu badan halus atau suksma sarira maupun badan kasar atau stulasarira.

Ritual atau caru memberi pengaruh terhadap bhuana agung, lalu bagaimana dengan yang melaksanakan caru yang dimaksud adalah bhuana alit atau mikrokosmos. Sebelumnya dijelaskan bahwa pengaruh ritual atau caru untuk bhuana agung adalah mampu menetralisir kosmos. Secara sederhana bila kita lihat dari Lontar Kala Tatwa dalam Pasek Swastika (2009:11) secara jelas menyebutkan bahwa bila bhuta sudah diberi persembahan maka bhuta akan berubah wujud menjadi Dewa yang selanjutnya menjaga kehidupan umat manusia. Sehingga caru ini akan mendatangkan ketenangan bagi umat manusia, secara sederhana seperti seseorang yang tinggal di lingkungan yang kotor dan kumuh pastinya tidak nyaman dan ketika lingkungan itu dibersihkan maka orang tersebut akan merasa nyaman, terhindar dari virus dan penyakit. Seperti itu pula 
mecaru, dimana ketika alam ini dinetralisir akan memberi dampak yang positif juga untuk manusia.

Donder dalam wawancara mengatakan bahwa "sebenarnya apa yang terjadi di alam ini adalah merupakan hasil dari erbuatan dan pikiran manusia". Apa yang dikatakan oleh Pak Donder senada dengan ajaran yoga yang terkenal dimana yang tertuang pada tulisan Stacey Lawson dalam Jayarava $(2010: 1)$ :

There is a famous yogic teaching: "Yad Bhavam Tad Bhavati." The most literal translation is: "You become as you think." But the Sanskrit language has many layers of meaning. It can also be interpreted as, "The state of mind and the state of matter are one," or "The light of the mind coalesces as matter." Through delving into this single statement, the yogis were able to apprehend the entire structure of creation through the mind.

Terjemahannya :

Ada ajaran yoga yang terkenal: "Yad Bhavam Tad Bhavati." Terjemahan yang paling harfiah adalah: "Anda menjadi seperti yang Anda pikirkan." Tapi bahasa Sanskerta memiliki banyak lapisan makna. Hal ini juga dapat diartikan sebagai, "Keadaan pikiran dan keadaan materi adalah satu," atau "Cahaya pikiran bersatu sebagai materi." Dengan menyelidiki satu pernyataan ini, para yogi mampu memahami keseluruhan struktur ciptaan melalui pikiran.

Berdasarkan kutipan artikel di atas dapat dipahami bahwa kita akan menjadi seperti yang kita pikirkan. Alam juga akan merespon sesuai dengan pikiran kita. Bila kita selalu berpikiran buruk maka keburukan yang datang kepada kita. Namun sebaliknya bila kita berpikir yang baik, maka kebaikan akan menjadi takdir kita. Caru atau ritual membantu manusia untuk memusatkan dan mengkonsentrasikan pikiran demi keharmonisan antara bhuana alit dan bhuana agung karena yang diharapkan adalah keharmonisan maka keharmonisanlah yang terjadi. Hubungan yang harmonis akan mendatangkan kebaikan dan kenyamanan terhadap kehidupan umat manusia.

\section{Kesimpulan}

Berdasarkan ulasan sebelumnya maka dapat disimpulkan bahwa :

a. Ajaran sekte bhairawa yang telah lebur bersama adat dan tradisi masyarakat Hindu Bali masih eksis dilaksanakan. Pelaksanaannya berjalan dengan baik di masyarakat dan tidak mengalami permasalahan. Ada beberapa hal yang mulai dirubah namun tidak menghilangkan esensi seperti misalnya lawar di beberapa daerah masih menggunakan daging mentah namun jumlahnya sedikit karena alasan kesehatan, namun kativitas itu masih dilakukan dan masih ada. Penggunaan arak, berem dan tuak sebagai bahan persembahan masih dilakukan. Pementasan Calon Arang juga masih di lakukan di Bali, bahkan di Pura Kebo Edan sendiri pementasan Calon Arang rutin dilakukan setahun sekali. Pemujaan terhadap Dewi Durga yang berstana di Pura Pauman juga rutin dilaksanakan.

b. Ajaran sekte Bhairawa yang sudah lebur bersama adat dan tradisi masyarakat Hindu Bali tentunya memberi pengaruh terhadap bhuana agung dan bhuana alit. Caru yang merupakan ritual bercorak bhairawa bertujuan untuk menetralisir alam serta menyomia para bhuta kala, memberi pengaruh yang positif untuk alam karena mampu untuk membersihkan dan mengembalikan alam beserta isinya kepada keadaan yang lebih baik. Apabila bhuana agung telah baik dan bersih maka akan memberi dampak yang positif pula untuk bhuana alit, dalam hal ini manusia yaitu berupa ketentraman dan ketenangan. Hubungan yang harmonis antara bhuana agung dan bhuana alit akan menciptakan ketemtraman dan ketenangan.

\section{DAFTAR PUSTAKA}

Donder I Ketut. 2012. The essence of animal 
sacrifice in balinese hindu ritual. International journal of multidisciplinary educational research

Donder, I Ketut. 2007. Kosmologi Hindu. Paramita : Surabaya

Indra Wirawan I Komang. 2016. Barong dan Rangda dalam dinamika religius masyarakat Bali. Paramita :Surabaya

Mandra, I Ketut, 2007, Vijnana Bhairawa atau Kesadaran Tuhan. Surabaya : Paramita

Pasek Swastika, I Ketut. 2009. Caru. CV. Kayumas Agung

Paul Michel Munoz, 2009, Kerajaan-Kerajaan Awal Kepulauan Indonesia dan Semenanjung Malaysia; Perkembangan Sejarah dan Budaya Asia Tenggara (Jaman Prasejarah-Abad XVI), Yogyakarta: Mitra Abadi

R.Soekmono, 1985, Pengantar Sejarah Kebudayaan Indonesia, Jilid 2, Yogyakarta: Kanisius

Shrii Shrii Anandamurti. 2016. Tantra Jalan Pembebasan. Ananda Marga Indonesia

Suamba, I.B. Putu, 2009, Siwa-Buddha di Indonesia Ajaran dan Perkembangannya, Denpasar : Widya Dharma

Subagiasta, I Ketut. 2007. Ahimsa dan Himsa http://phdi.or.id/artikel/ahimsa-dan-himsa 